\title{
7. On the Photosensitive Substances in Cones of the Human Retina.
}

\author{
By Minoru Nakashima. \\ Department of Ophthalmology, University of Tokyo. \\ (Comm. by Y. KUnO, M.J.A., Jan. 12, 1951.)
}

While the studies in visual purple, the photosensitive substance in the rods of retina, may go back to as early as 1877, the presence of photosensitive substances in the cones was first noticed in 1932, when v. Studnitz found a very strong, and by lighting quickly reduced, absorption of the cone retina of various animals by means of Pulfrich's stufen-photometer. The absorption curve of the extract of pure cone retina (tortoise, snake, etc.) has three humps in about 470, 560 and $670 \mathrm{~m} \mu$. The investigation of Hosoya carried out on tortoise in Formosa showed a similar curve.

The pure cone retina being difficult of acsess, the author attempted to reveal the absorption curve of the human cone substances. The method was based on the following premises: 1) The light acts only on the spot where it is absorbed, 2) if the photosensitive substances are decomposed by light, the sensitivity of the cones to light should be reduced, and 3) the quantity of decomposition of the photosensitive substances can be estimated by the time for a full regeneration, that is, the time required for completing the dark adaptation. As the procedures, the dark adapted human retina was illuminated by monochromatic light for five minutes, and then the period of time required for full restoration of the dark adaptation was calculated from the precisely measured adaptation curve.

In the first series of experiments, performed in conjunction with Mizutani, the monochrometer of Winkel-Zeiss was used. Owing to the unsatisfactory intensity of monochromatic light, the time for a full dark adaption of the macular region (visual angle $1^{\circ}$ ) did not exceed ten minutes. Consequently the difference according to wave length was not distinct, yet a complicate curve with

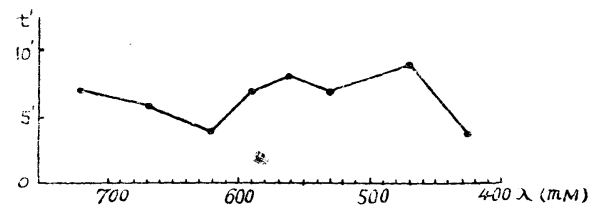

Fig. 1. Absorption of human cones, taken from adaptation time after monochromatic lighting. humps at 470,560 and $670-720 \mathrm{~m} \mu$ could be obtained (Fig. 1). 
As the data in the part of long waves were not constant and not distinct enough, another series of experiments were made in conjunction with Mazima by means of the double monochrometer of the Tokyo Optical Co., and a curve presenting distinctly three peaks at 470,560 and $670 \mathrm{~m} \mu$ and valleys at 530 and $640 \mathrm{~m} \mu$ was obtained (Fig. 2). This curve corresponds on the whole with the absorption curve of the photosensitive substances of cones reported by v. Studnitz.

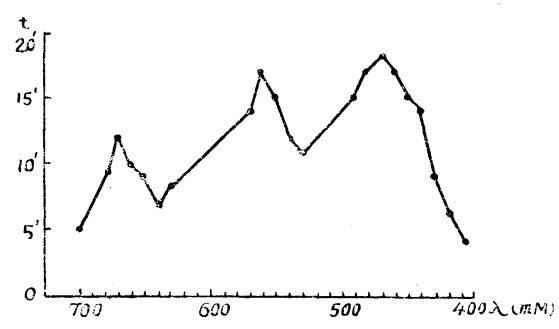

Fig. 2. Absorption spectrum of cone substance of human retina, obtained from adaptation time time after monochromatic illumination.

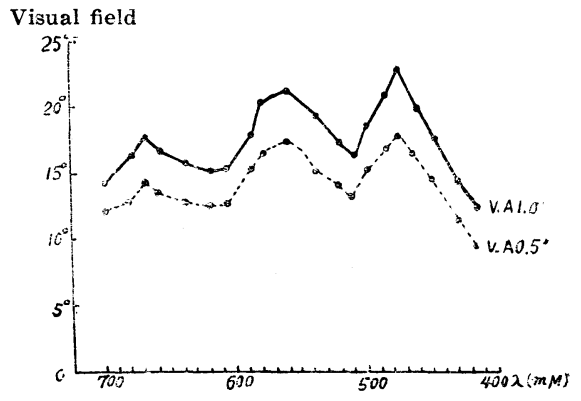

Fig. 3. Visual field for monochromatic light.

Whether such a curve derives from only one substance or three substances, each of which has an absorption maximum, may be estimated by measuring the width of monochromatic visual fields. In the periphery of the retina, the distribution of cones is not so dense that only one cone, and not two or more, seems to be more probably stimulated. If therefore the photosensitive substance contained in different cones is not uniform, the visual fields for different monochromatic stimulation may vary. Monochromatic lights with visual angle of $1^{\circ}$ were used and the visual field for each was carefully determined in collaboration with Ichikawa. As is shown in figure 3, the visual fields were not uniform, but varied considerably in different wave lengths.

This curve well corresponds in shape to that of the time of dark adaptation after previous monochromatic lighting in the macula lutea. The positions of humps and hollows of the former did not change in case a visual angle of $0.5^{\circ}$ was used, although the visual fields became a little narrower.

The above results suggest that the photosensitive substances in cones are not one, but three, each of which shows an absorption maximum at 470,560 and $670 \mathrm{~m} \mu$ respectively, and that each cone contains only one sort of them. 
I.

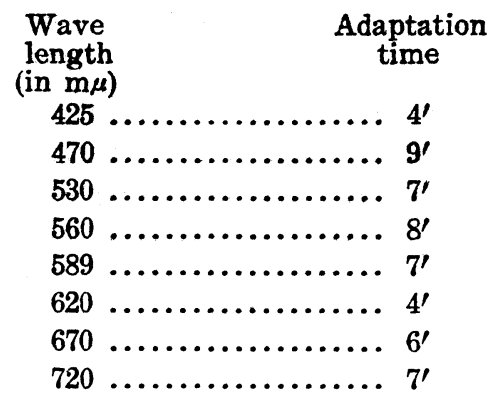

II.

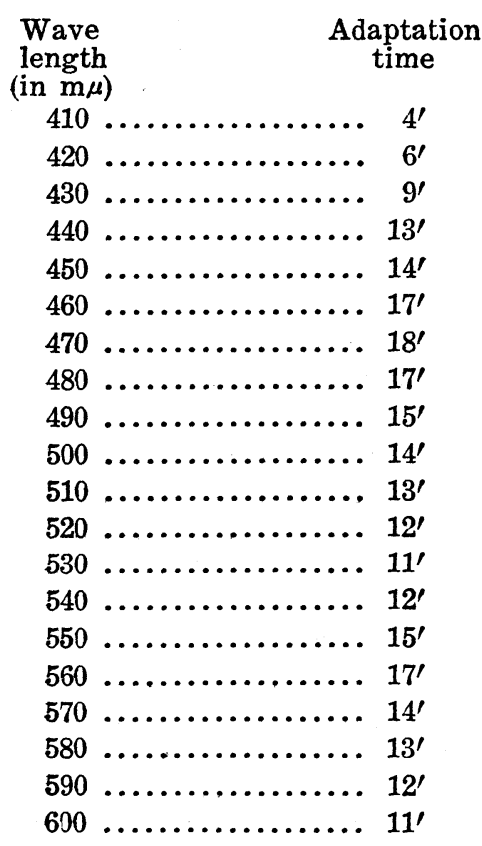

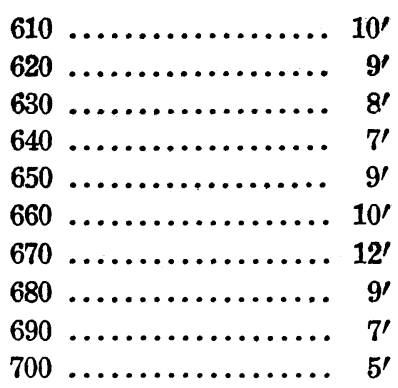

III.

Wave Visual field. length Visual angle (in $\mathrm{m} \mu) \quad\left(0.5^{\circ}\right) \quad\left(1.0^{\circ}\right)$

$418 \ldots \ldots \ldots . .9^{\circ} 40 \ldots . .12^{\circ} 17$

$430 \ldots \ldots \ldots 11^{\circ} 56 \ldots . .14^{\circ} 06$

$450 \ldots \ldots . .14^{\circ} 41 \ldots . .16^{\circ} 86$

$460 \ldots \ldots \ldots 16^{\circ} 64 \ldots . .19^{\circ} 84$

$475 \ldots \ldots \ldots .17^{\circ} 87 \ldots . .22^{\circ} 61$

$485 \ldots \ldots \ldots .16^{\circ} 83 \ldots . .21^{\circ} 00$

$500 \ldots \ldots . .15^{\circ} 30 \ldots . .18^{\circ} 67$

$511 \ldots \ldots . .13^{\circ} 19 . . . .16^{\circ} 24$

$520 \ldots \ldots \ldots 14^{\circ} 31 \ldots . .17^{\circ} 48$

$540 \ldots \ldots \ldots 16^{\circ} 06 \ldots . .19^{\circ} 64$

$550 \ldots \ldots . .26^{\circ} 69 \ldots .20^{\circ} 46$

$560 \ldots \ldots . .27^{\circ} 36 \ldots .21^{\circ} 07$

$570 \ldots \ldots . .17^{\circ} 17, \ldots .20^{\circ} 86$

$580 \ldots \ldots \ldots 16^{\circ} 43 \ldots .20^{\circ} 13$

$589 \ldots \ldots \ldots 15^{\circ} 31 \ldots . . .18^{\circ} 34$

$607 \ldots \ldots \ldots .12^{\circ} 61 \ldots . .15^{\circ} 16$

$620 \ldots \ldots \ldots 12^{\circ} 67 . \ldots .15^{\circ} 14$

$640 \ldots \ldots \ldots .12^{\circ} 94 \ldots . . .15^{\circ} 84$

$660 \ldots \ldots .13^{\circ} 63 \ldots . .16^{\circ} 57$

$670 \ldots \ldots \ldots 14^{\circ} 30 \ldots . .17^{\circ} 57$

$680 \ldots \ldots \ldots 12^{\circ} 94 \ldots . .16^{\circ} 16$

$700 \ldots \ldots \ldots 12^{\circ} 19 \ldots . .14^{\circ} 36$

\section{References.}

1) V. Studnitz: Pflügers Arch. ges. Physiol. 230 Bd. 614 (1932).

2) V. Studnitz: Pflügers Arch. ges. Physiol. 239 Bd. 515 (1937).

3) V. Studnitz: Klin. Monatsbl. f. Augenh. 109 (1943).

4) V. Studnitz: Naturwissensehaten $29 \mathrm{Jg} .47$ (1941).

5) Y. Mizutani \& M. Nakashima: Kagaku 13, 369 (1948).

6) Y. Mizutani : Acta Soc. Opht. Jap. Vol. 52, 113 (1948). 